\title{
Chemical Constituents from Aspidosperma illustre (Apocynaceae)
}

\author{
Lara F. Barbosa, Leda Mathias, Raimundo Braz-Filho and Ivo J. Curcino Vieira* \\ Laboratório de Ciências Químicas, Universidade Estadual do Norte Fluminense Darcy Ribeiro, \\ 28013-602 Campos dos Goytacazes-RJ, Brazil
}

\begin{abstract}
A partir de Aspidosperma illustre, foi obtido como produto natural um novo triterpeno da série oleanano, o olean-12-en-11 $\alpha$-metóxi-3 $\beta$-acetato (10), além dos triterpenos $\beta$-amyrina (3), lupeol (4), acetato de $\beta$-amyrina (5), acetato de lupeol (6), olean-12-en-28-hidróxi-3 $\beta$-tetradecanoato (7), olean-12-en-28-carboxi-3 $\beta$-hexadecanoato (8), ácido ursólico (9) e dois alcalóides indólicos monoterpênicos, $\beta$-ioimbina (1) e 1,2-desidroaspidospermidina (2). As substâncias isoladas foram identificadas através de métodos espectroscópicos, principalmente uni (RMN $\left.{ }^{1} \mathrm{H},{ }^{13} \mathrm{C}, \mathrm{APT}\right) \mathrm{e}$ bidimensionais $\left({ }^{1} \mathrm{H}-{ }^{1} \mathrm{H}-\mathrm{COSY},{ }^{1} \mathrm{H}-{ }^{1} \mathrm{H}-\mathrm{NOESY}\right.$, HMQC e HMBC) e de massas, envolvendo também comparação com dados de literatura.
\end{abstract}

A new natural product oleanane-type triterpene, olean-12-ene- $11 \alpha$-methoxy-3 $\beta$-acetate (10) was isolated from Aspidosperma illustre, together with $\beta$-amyrin (3), lupeol (4), $\beta$-amyrin acetate (5), lupeol acetate (6), olean-12-ene-28-hydroxy-3 $\beta$-tetradecanoate (7), olean-12-ene-28-carboxy$3 \beta$-hexadecanoate $(\mathbf{8})$, ursolic acid (9) triterpenes, and two monoterpenic indole alkaloids, $\beta$-yoimbine (1) and 1,2-dehydroaspidospermidine (2). These compounds were characterized on their spectral data basis, mainly one- $\left({ }^{1} \mathrm{H},{ }^{13} \mathrm{C}\right.$, APT $)$ and two-dimensional $\left({ }^{1} \mathrm{H}-{ }^{1} \mathrm{H}-\mathrm{COSY},{ }^{1} \mathrm{H}-{ }^{1} \mathrm{H}-\right.$ NOESY, HMQC and HMBC) NMR, and mass spectra, involving also comparison with data from the literature.

Keywords: Aspidosperma illustre, Apocynaceae, oleanane triterpenes, alkaloids

\section{Introduction}

The Aspidosperma (Apocynaceae) genus is endemic to Americas and is found mainly in regions between Mexico and Argentina. ${ }^{1}$ Aspidosperma genus continues to be fascinating as an expressive source of indole alkaloids with novel skeletons, ${ }^{2}$ which are interesting from a biosynthetic perspective and reported biological properties. ${ }^{2,3}$ Species of the Aspidosperma genus are applied broadly by popular medicine as potential antimalarial agents, leishmaniasis treatment, uterus and ovary inflammation, as contraceptive, in diabetes, in stomach problems, against cancer, fever and rheumatism. ${ }^{3}$

Aspidosperma illustre, commonly known as "TambuPequiá" in Atlantic forests in the North of Espírito Santo State, appears as a tree of $5-20 \mathrm{~m}$. This species is not reported on studies of chemical composition described in the literature.

In the present paper, we describe the isolation and characterization of a novel oleanane-type triterpene,

\footnotetext{
*e-mail: curcino@uenf.br
}

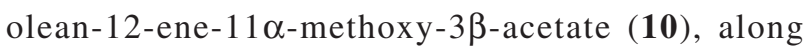
with seven known triterpenes, $\beta$-amyrin (3), lupeol (4), $\beta$-amyrin acetate (5), lupeol acetate (6), olean-12-ene28 -hydroxy-3 $\beta$-tetradecanoate (7), olean-12-ene-28carboxy-3 $\beta$-hexadecanoate (8), ursolic acid (9) and two known monoterpenic indole alkaloids, $\beta$-yoimbine (1) and 1,2-dehidroaspidospermidine (2). The structures of known and new compound are being mentioned for the first time in this species and were established on the basis of spectral data, mainly ${ }^{1} \mathrm{H}$ and ${ }^{13} \mathrm{C}$ (1D and 2D) NMR spectra, mass spectrometry and by comparison with literature data.

\section{Results and Discussion}

The hexane and $\mathrm{MeOH}$ extracts of stem bark and leaves of A. illustre were subjected to a classical chromatographic methods to yield the a new oleanane-type triterpene, olean-12-ene-11 $\alpha$-methoxy-3 $\beta$-acetate (10), in addition to known, $\beta$-amyrin (3), ${ }^{4}$ lupeol (4), ${ }^{4} \beta$-amyrin acetate (5), ${ }^{4}$ lupeol acetate $(6),{ }^{4}$ olean-12-ene-28-hydroxy$3 \beta$-tetradecanoate (7), ${ }^{4}$ olean-12-ene-28-carboxy-3 $\beta$ hexadecanoate $(\mathbf{8}),{ }^{5,6}$ ursolic acid $(\mathbf{9}),{ }^{4} \beta$-yoimbine $(\mathbf{1})^{7-9}$ 
and 1,2-dehydroaspidospermidine (2), ${ }^{10}$ were identified on the basis of ${ }^{1} \mathrm{H}$ and ${ }^{13} \mathrm{C}$ NMR spectral data, including ${ }^{1} \mathrm{H}-{ }^{-1} \mathrm{H}-\mathrm{COSY},{ }^{1} \mathrm{H}-{ }^{-1} \mathrm{H}-\mathrm{NOESY}$, HSQC and HMBC NMR experiments, ${ }^{11,12}$ which were also used to complete unambiguous ${ }^{1} \mathrm{H}$ and ${ }^{13} \mathrm{C}$ chemical shift assignments of the triterpenoid 10, the new natural product.

The pentacyclic triterpene (10) was obtained as an amorphous solid. Comparative analysis of $\left\{{ }^{1} \mathrm{H}\right\}$ - and APT${ }^{13} \mathrm{C}$ NMR spectra (Table 1), involving the corroboration of ${ }^{1} \mathrm{H}$ NMR spectra (1D ${ }^{1} \mathrm{H}$ NMR and $2 \mathrm{D}{ }^{1} \mathrm{H}-{ }^{1} \mathrm{H}-$ COSY), allowed to recognize the presence of 33 signals corresponding to eight nonhydrogenated $\left[(C)_{8}: \operatorname{six~}^{3}\right.$, two $\mathrm{sp}^{2}$ (including one carbonyl groups at $\delta_{\mathrm{C}} 171.0$ and one $\mathrm{sp}^{2}$ olefinic at $\delta_{\mathrm{C}}$ 149.7], six methine [(CH) : five $\mathrm{sp}^{3}$ (including two oxygenated linked to acetyl group at $\delta_{\mathrm{C}} 80.8$ and to methoxyl function at $\left.\delta_{\mathrm{C}} 75.7\right)$ and one $\mathrm{sp}^{2}$ olefinic at $\left.\delta_{\mathrm{C}} 121.8\right]$, nine methylene $\left[\left(\mathrm{CH}_{2}\right)_{9}\right.$, all sp $\left.{ }^{3}\right]$ and ten methyl $\left[\left(\mathrm{CH}_{3}\right)_{10}\right.$ : including two oxygenated attributed to acetate $\left(\delta_{\mathrm{C}}\right.$ $\left.21.4 / \delta_{\mathrm{H}} 2.06, \mathrm{~s}\right)$ and methoxyl groups $\left.\left(\delta_{\mathrm{C}} 53.4 / \delta_{\mathrm{H}} 3.21, \mathrm{~s}\right)\right]$ carbon atoms, allowing to deduce the expanded molecular formula $(\mathrm{C})_{7}(\mathrm{C}=\mathrm{O})(\mathrm{CH})_{6}\left(\mathrm{CH}_{2}\right)_{9}\left(\mathrm{CH}_{3}\right)_{9}\left(\mathrm{OCH}_{3}\right)$ for $\mathbf{1 0}$.

The LREI-MS $(70 \mathrm{eV})$ spectrum of $\mathbf{1 0}$ showed of molecular peak $\left[\mathrm{M}^{+}\right]$at $\mathrm{m} / \mathrm{z} 498$ Daltons, allowing in conjugation with the ${ }^{13} \mathrm{C}$ NMR spectral data to propose molecular formula $\mathrm{C}_{33} \mathrm{H}_{54} \mathrm{O}_{3}$ (10), containing seven degrees of unsaturation and consistent with the presence of one acetyl group and one double bond in a pentacyclic triterpenoid acetylated and methoxylated, compatible with the structure triterpenic sustaining an acetate group at carbon atom CH-3 $\left[\delta_{\mathrm{C}} 80.8 / \delta_{\mathrm{H}} 4.51\right.$ (dd, $J 8.8$ and $7.6 \mathrm{~Hz})]$ in an $\beta$-amyrin skeleton $\left(3, \beta\right.$-amyrin). ${ }^{4}$ In fact, heteronuclear long-range coupling $\left({ }^{3} J_{\mathrm{CH}}\right)$ of this carbon atom $\left(\delta_{\mathrm{C}} 80.8\right)$ with $\mathrm{H}-5\left(\delta_{\mathrm{H}} 0.87\right.$, value approximated deduced through of HMQC spectrum) and both methyl groups linked to quaternary carbon C-4 $\left[\delta_{\mathrm{H}} 0.85(3 \mathrm{H}-23)\right.$ and 0.88 (3H-24)], as shown in Table 1.

The ${ }^{13} \mathrm{C}$ NMR spectrum of $\mathbf{1 0}$ revealed signals at $\delta_{\mathrm{C}}$ $121.8(\mathrm{CH}-12)$ and at $\delta_{\mathrm{C}} 149.7(\mathrm{C}-13)$, indicating the presence of a trisubstituted double bond. In the HMQC spectrum a cross-peak correlation ${ }^{1} J_{\mathrm{CH}}$ was observed between the $\mathrm{CH}-12$ at $\delta_{\mathrm{C}} 121.8$ and the singlet signal at $\delta_{\mathrm{H}}$ 5.30 , which was assigned to the vinylic hydrogen.

The stereochemistry of the stereogenic carbons $\mathrm{CH}-3$ and $\mathrm{CH}-11$ of $\mathbf{1 0}$ was determined from the coupling constants of relevant hydrogens and from the observed ${ }^{1} \mathrm{H}-{ }^{1} \mathrm{H}-\mathrm{NOESY}$. The values corresponding to vicinal interaction $\left({ }^{3} J_{\mathrm{H}, \mathrm{H}}\right)$ between the hydrogen atoms $\mathrm{H}-3$ and $\mathrm{H}-2$ suggested axial-axial interaction, since the $\mathrm{H}-3$ signal $\left(\delta_{\mathrm{H}}\right.$ 4.51 , dd, $J 8.8$ and $7.6 \mathrm{~Hz}$ ) revealed axial-axial coupling $(J 8.8 \mathrm{~Hz}$, Table 1$)$; similarly the multiplicity observed in the signal of the hydrogen $\mathrm{H}-11\left(\delta_{\mathrm{H}} 3.88, \mathrm{dd}, J 9.4\right.$ and $\left.3.5 \mathrm{~Hz}\right)$
Table 1. ${ }^{1} \mathrm{H}(400 \mathrm{MHz})$ and ${ }^{13} \mathrm{C}(100 \mathrm{MHz})$ NMR data of triterpene (10), in $\mathrm{CDCl}_{3}$ as solvent and TMS used as internal reference. Chemical shifts $(\delta, \mathrm{ppm})$ and coupling constants $(\mathrm{J}, \mathrm{Hz}$, in parenthesis)*

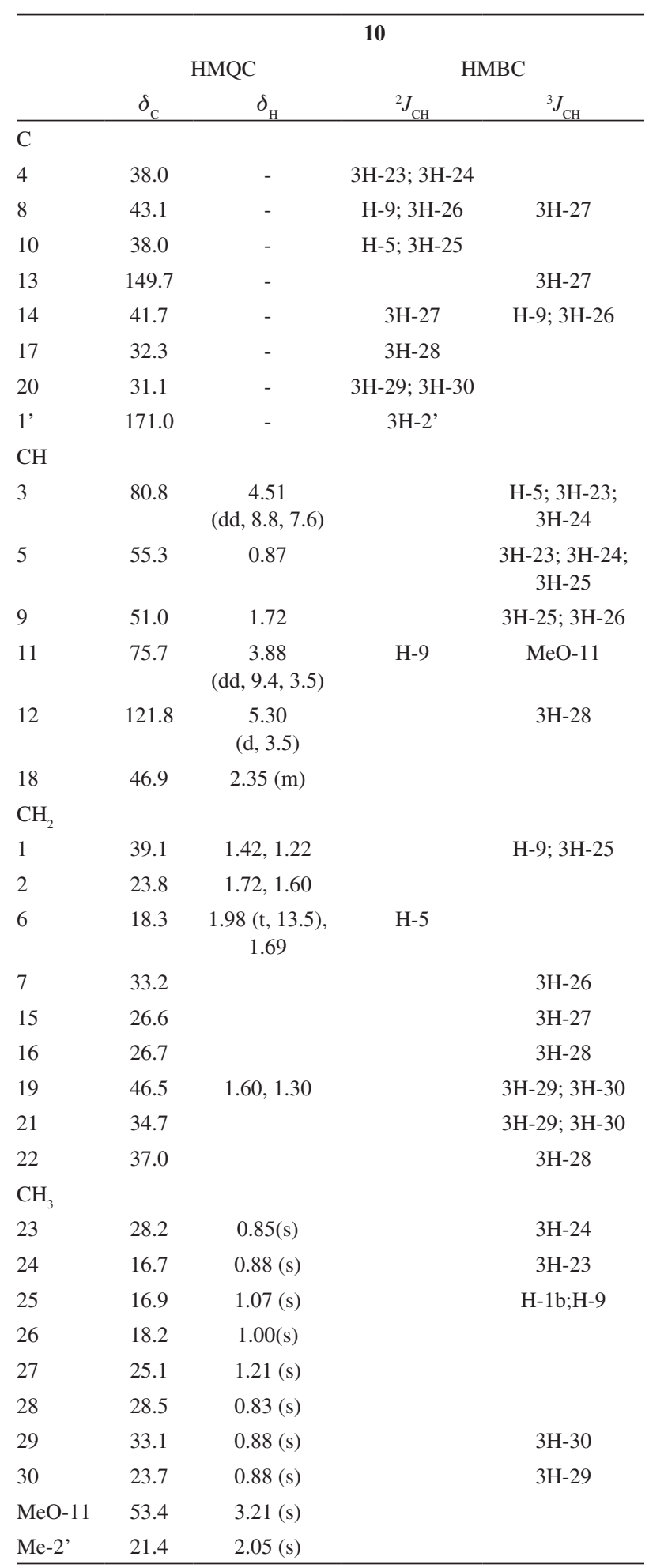

*Number of hydrogens bound to carbon atoms deduced by comparative analysis of $\left\{{ }^{1} \mathrm{H}\right\}$ - and DEPT- ${ }^{13} \mathrm{C}$ NMR spectra. Chemical shifts and coupling constants $(J)$ were obtained of $1 \mathrm{D}{ }^{1} \mathrm{H}$ NMR spectrum. ${ }^{1} \mathrm{H}-{ }^{1} \mathrm{H}-\mathrm{COSY}$ and ${ }^{1} \mathrm{H}-{ }^{1} \mathrm{H}-\mathrm{NOESY}$ experiments were also used to these assignments. Superimposed ${ }^{1} \mathrm{H}$ signals are described without multiplicity and chemical shifts deduced by HMQC and HMBC spectra. 
and both H-12 $\left(\delta_{\mathrm{H}} 5.30, \mathrm{~d}, J 3.5 \mathrm{~Hz}\right)$ and $\mathrm{H}-9\left(\delta_{\mathrm{H}} 1.72\right)$ allowed to recognize axial-axial interaction of $\mathrm{H}-11 \mathrm{ax}$ with $\mathrm{H}-9 \mathrm{ax}$, since the $\mathrm{H}-11$ signal revealed axial-axial coupling $(J 9.4 \mathrm{~Hz}$, Table 1) and H-11ax and H-12eq by $=3.5 \mathrm{~Hz}$, consistent with the relative configuration shown in 10a. Consistent with these observations, the ${ }^{1} \mathrm{H}-{ }^{1} \mathrm{H}$-NOESY spectrum of $\mathbf{1 0}$ showed cross-peaks assigned to dipolar interaction (spatial proximity, vide 10a) of $\mathrm{H}-11\left(\delta_{\mathrm{H}} 3.88\right)$ with $3 \mathrm{H}-25\left(\delta_{\mathrm{H}} 1.07\right)$ and $3 \mathrm{H}-26\left(\delta_{\mathrm{H}} 1.00\right)$; hydrogen atoms of the methyl group present in the $3 \beta$ - $O$-acetyl $\left(\delta_{\mathrm{H}} 2.05\right)$ with both $3 \mathrm{H}-23\left(\delta_{\mathrm{H}} 0.85\right)$ and $3 \mathrm{H}-24\left(\delta_{\mathrm{H}} 0.88\right)$.

The oxidation at $\mathrm{CH}-11$ of $\mathbf{1 0}$ is adequate to introduce significant modification in fragmentation of this pentacyclic triterpene containing double bond between the carbon atoms $\mathrm{CH}-12$ e C-13 in the mass spectrometer, revealing the absence of peaks produce by reaction Retro-DielsAlder (RDA), as observed in other triterpenes with such characteristics. ${ }^{13,14}$

Confirmation of structure $\mathbf{1 0}$ was done by comparison with authentic sample of derivative monoacetate of triterpene 11- $\alpha$-methoxy- $\beta$-amyrin isolated from Myroxylon balsamum (Fabaceae). ${ }^{15}$

According to the literature, the triterpene $\mathbf{1 0}$ was also obtained as an intermediate reaction by allylic oxidation by $N$-bromosuccimide with $\beta$-amyrin acetate. ${ }^{16}$

Thus, the pentacyclic isolated from Aspidosperma illustre was characterized as olean-12-ene-11 $\alpha$-methoxy$3 \beta$-acetate (10), a new natural product.<smiles></smiles>

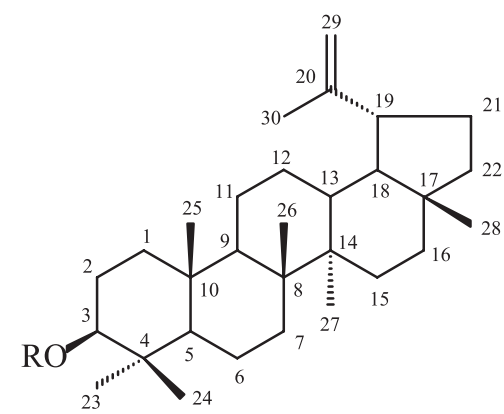

4. $\mathrm{R}=\mathrm{H}$

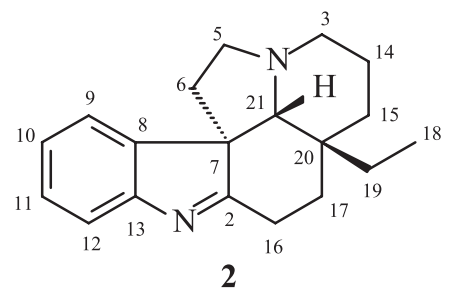

3. $\mathrm{R}^{1}=\mathrm{R}^{2}=\mathrm{R}^{5}=\mathrm{H} ; \mathrm{R}^{3}=\mathrm{R}^{4}=\mathrm{CH}_{3}$

5. $\mathrm{R}^{1}=\mathrm{Ac} ; \mathrm{R}^{2}=\mathrm{R}^{5}=\mathrm{H} ; \mathrm{R}^{3}=\mathrm{R}^{4}=\mathrm{CH}_{3}$

7. $\mathrm{R}^{1}=\mathrm{CO}\left(\mathrm{CH}_{2}\right)_{12} \mathrm{CH}_{3} ; \mathrm{R}^{2}=\mathrm{R}^{5}=\mathrm{H}$; $\mathrm{R}^{3}=\mathrm{CH}_{2} \mathrm{OH} ; \mathrm{R}^{4}=\mathrm{CH}_{3}$

9. $\mathrm{R}^{1}=\mathrm{R}^{2}=\mathrm{R}^{4}=\mathrm{H} ; \mathrm{R}^{3}=\mathrm{COOH} ; \mathrm{R}^{5}=\mathrm{CH}_{3}$ 11. $\mathrm{R}^{1}=\mathrm{R}^{2}=\mathrm{R}^{5}=\mathrm{H} ; \mathrm{R}^{3}=\mathrm{COOH} ; \mathrm{R}^{4}=\mathrm{CH}_{3}$

6. $\mathrm{R}=\mathrm{Ac}$<smiles>CCCCCCCCCCCCCCCC(C)=O</smiles><smiles>CC1(C)CCC2(C(=O)O)CC[C@]3(C)C(=CCC4[C@@]5(C)CCC(O)C(C)(C)C5CC[C@]43C)C2C1</smiles>

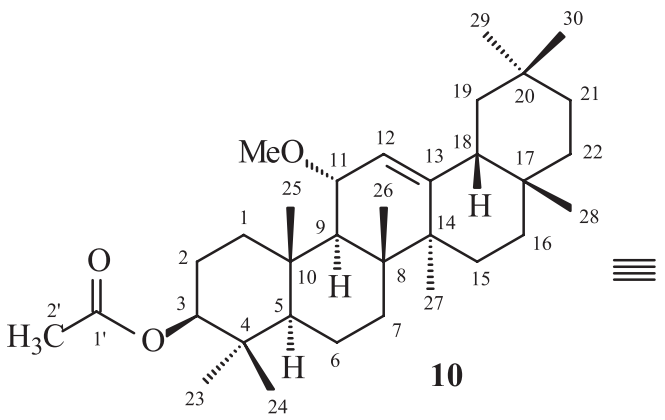

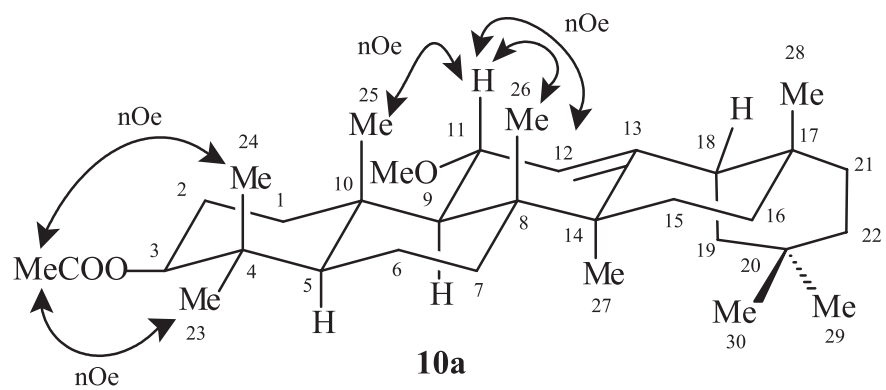

Figure 1. Structure of the compounds isolated from A. illustre. 
The results of the extensive application of $1 \mathrm{D}$ and 2D NMR spectral techniques were also used to confirm the structure and to establish the ${ }^{1} \mathrm{H}$ and ${ }^{13} \mathrm{C}$ resonance assignments of $\mathbf{1 0}$ (Table 1).

\section{Experimental}

\section{General procedures}

Optic rotation measures were obtained on a Perkin Elmer 343 digital polarimeter. Melting points were obtained on a Microquímica MQRPF and are uncorrected. FTIR spectra were recorded on a FTIR-8300 Shimadzu spectrometer using KBr disk. ESI-MS (high resolution) mass spectra were obtained on a MICROMASSUltrOTOF-Q (Brüker Daltonics, Billerica, MA) mass spectrometer, using the negative ion mode of analysis and EI-MS (low resolution) mass spectra were obtained on Shimadzu QP5050A mass spectrometer. Column chromatographic purifications were carried out over silica gel (70-230 mesh). Silica gel $60 \mathrm{~F}_{254}$ was used in thin layer chromatography analysis.

${ }^{1} \mathrm{H}$ and ${ }^{13} \mathrm{C}$ NMR spectra were measured on a Jeol Eclipse 400 spectrometer, operating at $400\left({ }^{1} \mathrm{H}\right)$ and $100\left({ }^{13} \mathrm{C}\right) \mathrm{MHz}$. $\mathrm{CDCl}_{3}$ was used as solvent and TMS as internal reference. Chemical shifts are given in the $\delta$ scale (ppm) and coupling constants $J$ in Hz. One dimensional (1D) ${ }^{1} \mathrm{H}$ and ${ }^{13} \mathrm{C}$ NMR spectra were acquired under standard conditions by using a direct detection $5 \mathrm{~mm}$ ${ }^{1} \mathrm{H} /{ }^{13} \mathrm{C}$ dual probe. Standard pulse sequences were used for two dimensional spectra by using a multinuclear inverse detection $5 \mathrm{~mm}$ probe with field gradient.

\section{Plant materials}

The stem barks and leaves of Aspidosperma illustre (Vell.) Kuhlm. \& Piraja were collected in November 2004 at Reserva Florestal de Linhares, Linhares, Espírito Santo State, Brazil. A voucher specimen (CVRD 338) is deposited at the Reserva Florestal Vale do Rio Doce Herbarium, Linhares, Espírito Santo State.

\section{Extraction and isolation}

Dried and powdered stem bark $(3.08 \mathrm{~kg})$ from A. illustre (Vell.) Kuhlm. and Piraja were extracted with hexane and methanol at room temperature, furnishing, after solvent evaporation, $10.1 \mathrm{~g}$ and $46.6 \mathrm{~g}$ of crude hexane and methanol extracts, respectively.

The hexane extract $(10.1 \mathrm{~g})$ from stem bark was chromatographed over silica gel column with a gradient of hexane/ethyl acetate to afford five fractions. Fraction 1 $(1.83 \mathrm{~g})$ was rechromatographed over a silica gel column with a gradient of hexane/ethyl acetate yielding of a mixture 5 and $\mathbf{6}(15.0 \mathrm{mg})$. Fraction $2(1.0 \mathrm{~g})$ and $5(848.7 \mathrm{mg})$ was rechromatographed over a silica gel column with a gradient of hexane/ethyl acetate supplying of a mixture 3 and $4(42.0 \mathrm{mg})$. Fraction 3 (3.26 g) presented as an amorphous white solid identified as compound (3). Fraction $4(682.4 \mathrm{mg})$ was rechromatographed over a silica gel column with a gradient of hexane/ethyl acetate yielding of a compound (10) $(7.0 \mathrm{mg})$.

A portion of the methanol extract $(10.0 \mathrm{~g})$ was chromatographed over silica gel column with a gradient of $\mathrm{CH}_{2} \mathrm{Cl}_{2} / \mathrm{MeOH}$ supplying four fractions. Fraction 1 (589.0 mg) was rechromatographed over silica gel column with a gradient of $\mathrm{CH}_{2} \mathrm{Cl}_{2} / \mathrm{MeOH}$ yielding of a compound $(7,9.0 \mathrm{mg})$ and mixture of compounds $(\mathbf{3}) \mathrm{e}(\mathbf{4})(53.0 \mathrm{mg})$. Fraction $3(360.0 \mathrm{mg})$ was rechromatographed over silica gel column with a gradient of $\mathrm{CH}_{2} \mathrm{Cl}_{2} / \mathrm{MeOH}$ furnishing two compounds $(\mathbf{1}, 319.0 \mathrm{mg})$ and $(\mathbf{2}, 10.0 \mathrm{mg})$.

Dried and powdered leaves $(1.78 \mathrm{~kg})$ were extracted with methanol at room temperature, furnishing, after solvent evaporation, $159.5 \mathrm{~g}$ of crude methanol extract.

A portion of the methanol extract $(40.0 \mathrm{~g})$ was partitioned with $\mathrm{CH}_{2} \mathrm{Cl}_{2} / \mathrm{H}_{2} \mathrm{O}$, supplying $\mathrm{CH}_{2} \mathrm{Cl}_{2}$ phase $(23.2 \mathrm{~g})$. A portion of the $\mathrm{CH}_{2} \mathrm{Cl}_{2}$ phase $(5.0 \mathrm{~g})$ was chromatographed over a silica gel column with a gradient of hexane/ethyl acetate supplying seven fractions. The fractions $4(603.3 \mathrm{mg})$ and $5(4.1 \mathrm{~g})$ after successive chromatography's furnishing of compound (8) (138.4 mg). The fraction seven $(963.7 \mathrm{mg}$ ) was rechromatographed over a silica gel column with a gradient of hexane/ethyl acetate yielding of compound (9) $(83.8 \mathrm{mg}$ ).

The water phase (23.2 g) was extracted with ethyl acetate furnishing the ethyl acetate phase $(5.35 \mathrm{~g})$. The portion of the ethyl acetate phase $(2.0 \mathrm{~g})$ was chromatographed over silica gel column with a gradient of $\mathrm{CH}_{2} \mathrm{Cl}_{2} / \mathrm{MeOH}$ supplying thirteen fractions. The fractions $3(16.6 \mathrm{mg})$ and $5(12.7 \mathrm{mg})$ were submitted to a preparative TLC with hexane/ethyl acetate supplied by compounds $7(7.0 \mathrm{mg})$ and $\mathbf{3}$ and $\mathbf{4}$ mixture (4.0 mg), respectively.

\section{Transesterification reaction}

After purification, the triterpene $\mathbf{8}$ was submitted to transesterification reaction with boron trifluorate methanol $\left(\mathrm{BF}_{3}-\mathrm{MeOH}\right)$. In a flask were added $20 \mathrm{mg}$ of triterpene 8 and $5 \mathrm{~mL}$ of $\mathrm{BF}_{3}-\mathrm{MeOH} 20 \%$. The solution was heated to $90{ }^{\circ} \mathrm{C}$ for $10 \mathrm{~h}$. After was added $10 \mathrm{~mL}$ of $\mathrm{H}_{2} \mathrm{O}$ to the reaction and the aqueous phase separated from the organic phase by liquid-liquid extraction with hexane. The organic 
phase was concentrated, dried with $\mathrm{Na}_{2} \mathrm{SO}_{4}$ and evaporated for subsequent analysis of gas chromatography.

Olean-12-ene-11 $\alpha$-methoxy-3 $\beta$-acetate (10)

Amorphous solid, mp $148-152{ }^{\circ} \mathrm{C} ;[\alpha]_{\mathrm{D}}^{23}=+8.06^{\circ}$ $\left(\mathrm{CHCl}_{3}, c\right.$ 0.062); LREI-MS (rel. int.) $498\left(29, \mathrm{M}^{+\bullet}\right), 483$ (7, $\mathrm{M}$ - Me•), 466 (21, M - MeOH), 451 (9, M - MeOH - Me•), 391 (8, M - MeOH - Me - AcOH), 293 (32), 255 (58), 253 (20), 191 (41); ${ }^{1} \mathrm{H}$ and ${ }^{13} \mathrm{C}$ NMR: see Table 1.

\section{Supplementary Information}

Supplementary data are available free of charge at http://jbcs.sbq.org.br, as PDF file.

\section{Acknowledgments}

The authors thank Fundação de Amparo à Pesquisa do Estado do Rio de Janeiro (FAPERJ-RJ-Brasil) for visitant research fellowship and grants, to Conselho Nacional de Desenvolvimento Científico (CNPq-Brasil) for research fellowship. We are grateful to Prof. Norberto Peporine Lopes (FCFRP-USP) for the high-resolution mass spectra.

\section{References}

1. Pereira, M. M.; Jácome, R. L. R. P.; Alcântara, A. F. C.; Alves, R. B.; Raslan, D. S.; Quim. Nova 2007, 30, 1.

2. Oliveira, V. B.; Vieira, I. J. C.; Braz-Filho, R.; Mathias, L.; Lopes, N. P.; Crotti, A. E. M.; Uchoa, D. E. A.; J. Braz. Chem. Soc. 2009, 20, 753.

3. Oliveira, V. B.; Freitas, M. S. M.; Mathias, L.; Braz-Filho, R.; Vieira, I. J. C.; Rev. Bras. Pl. Med. 2009, 11, 92.
4. Ahmad,V. U.; Rahman, A.U.; Handbook of Natural Products Data, Pentacyclic Triterpenoids, Vol. 2, Elsevier: New York, 1994.

5. Carvalho, G. J.; Carvalho, M. G.; Ferreira, D. T.; Faria, T. J.; Braz-Filho, R.; Quim. Nova 2001, 24, 24.

6. Mallavadhani, U. V.; Mahapatra, A.; Raja, S. S.; Manjula, C.; J. Agric. Food Chem. 2003, 51, 1952.

7. Breitmaier, E.; Voelter, W.; Carbon-13 NMR Spectroscopy: High-Resolution Methods and Applications in Organic Chemistry and Biochemistry, $3^{\text {rd }}$ ed., VCH: Weinheim, 1987.

8. Shamma, M.; Carbon-13 NMR Shift Assignments of Amines and Alkaloids, Plenum Press: New York, 1979.

9. Malik, A.; Afza, N.; Siddiqui, S.; Heterocycles 1981, 16, 1727.

10. Hugel, G.; Royer, D.; Sigaut, F.; Levy, J.; J. Org. Chem. 1991, $56,4631$.

11. Claridge, T. D. W.; High-Resolution NMR Techniques in Organic Chemistry; Pergamon: Amsterdam, 1999.

12. Friebolin, H.; Basic One and Two-Dimensional NMR Spectroscopy; $2^{\text {nd }}$ ed., VCH: New York, 1993.

13. Barnes, R. A.; Pereira, A. L.; Scofield, T. C. V.; Braz-Filho, R.; Pinto, A. C.; Chem. Pharm. Bull. 1984, 32, 3674.

14. Branco, A.; Pinto, A. C.; Braz-Filho, R.; An. Acad. Bras. Cienc. 2004, 76, 505.

15. Mathias, L.; Vieira, I. J. C.; Braz-Filho, R.; Rodrigues-Filho, E.; J. Braz. Chem. Soc. 2000, 11, 195.

16. Finucane, B. W.; Thomson, J. B.; J. Chem. Soc. Perkin I 1972, 14, 1856.

Received: September 13, 2009 Web Release Date: March 22, 2010 


\section{Chemical Constituents from Aspidosperma illustre (Apocynaceae)}

\section{Lara F. Barbosa, Leda Mathias, R. Braz-Filho and Ivo J. Curcino Vieira* \\ Laboratório de Ciências Químicas, Universidade Estadual do Norte Fluminense Darcy Ribeiro, 28013-602 Campos dos Goytacazes-RJ, Brazil}

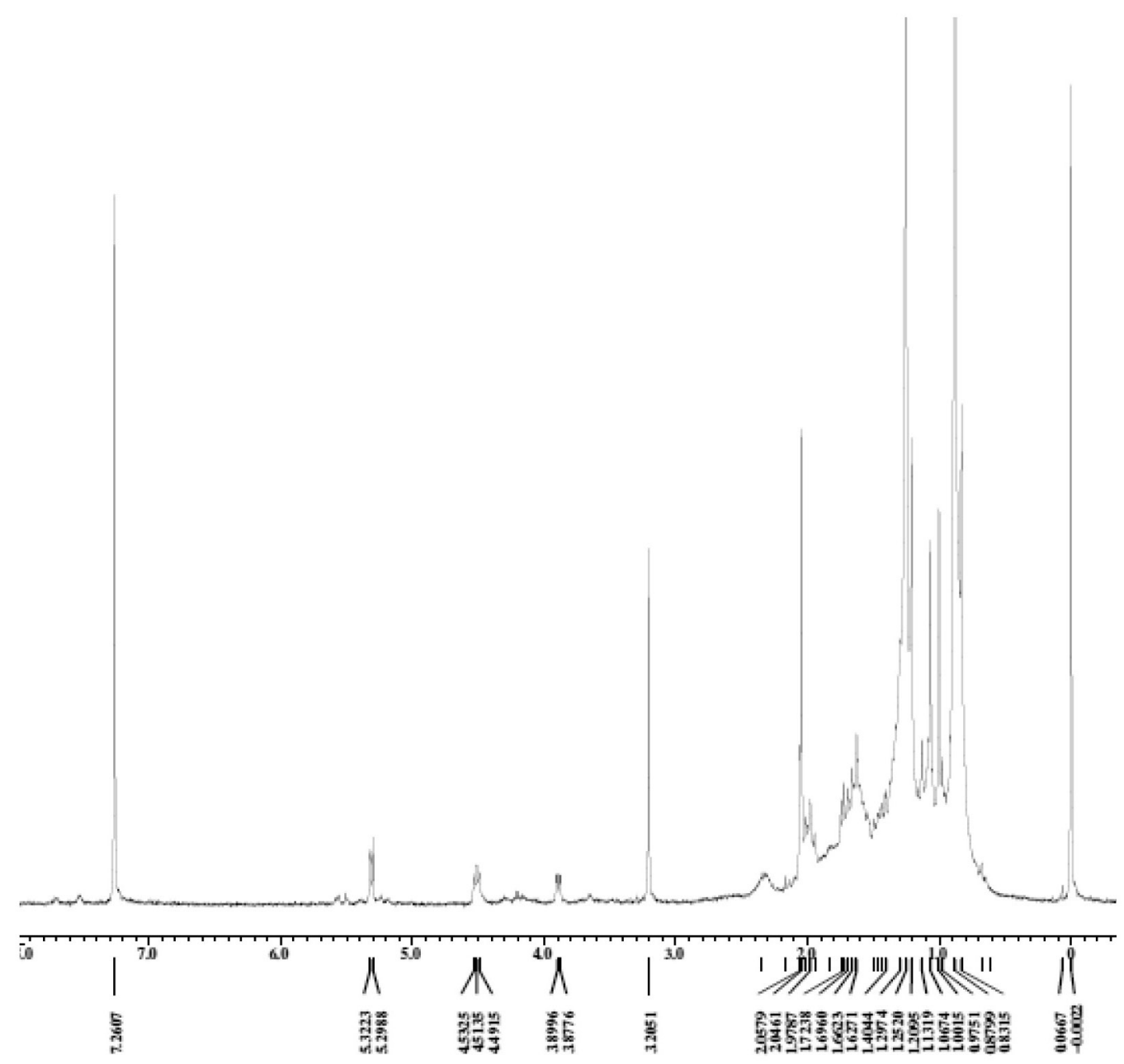

Figure S1. ${ }^{1} \mathrm{H}$ NMR spectrum of triterpene $10\left(400 \mathrm{MHz}, \mathrm{CDCl}_{3}\right)$.

*e-mail: curcino@uenf.br 


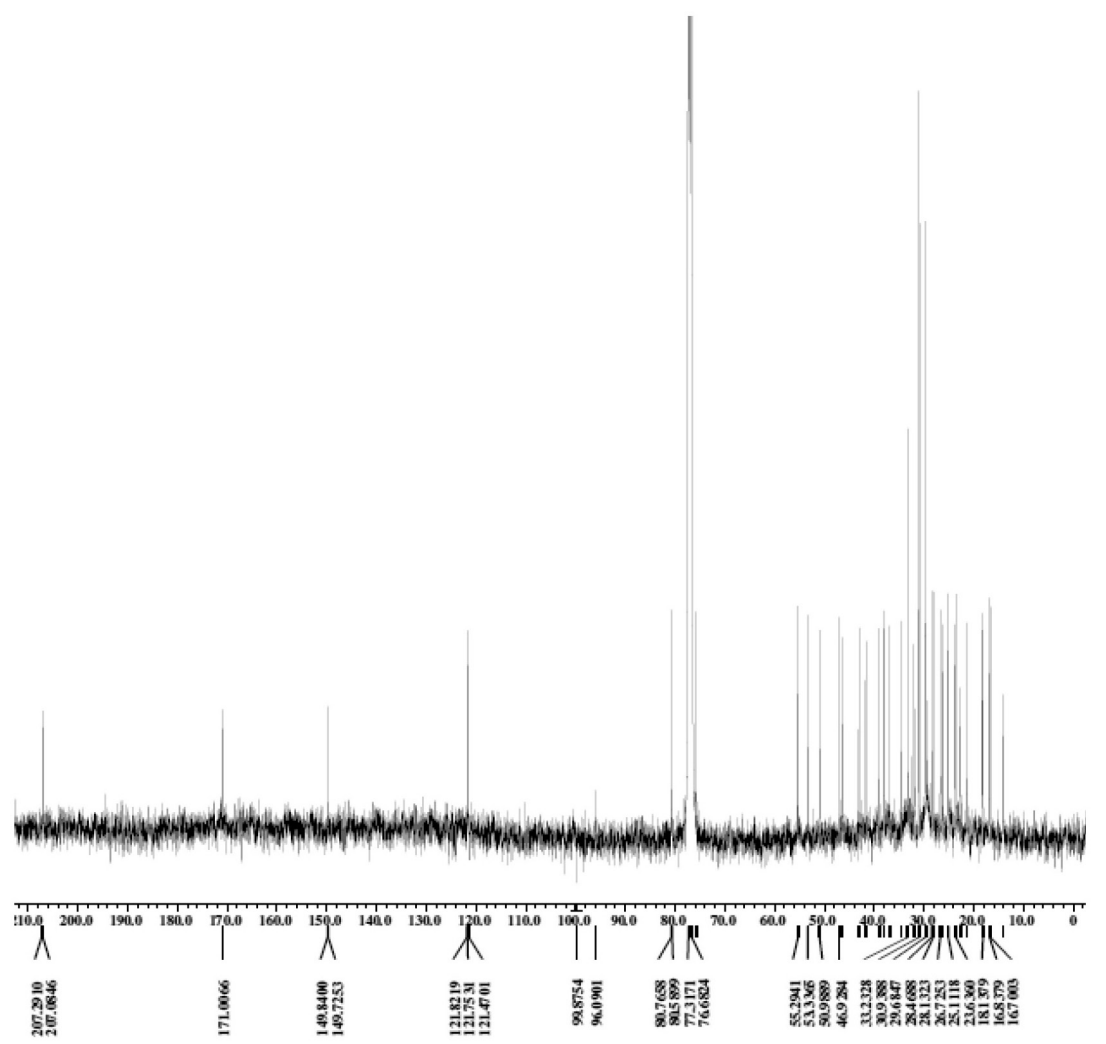

Figure S2. ${ }^{13} \mathrm{C}$ NMR spectrum of triterpene $10\left(100 \mathrm{MHz}, \mathrm{CDCl}_{3}\right)$.

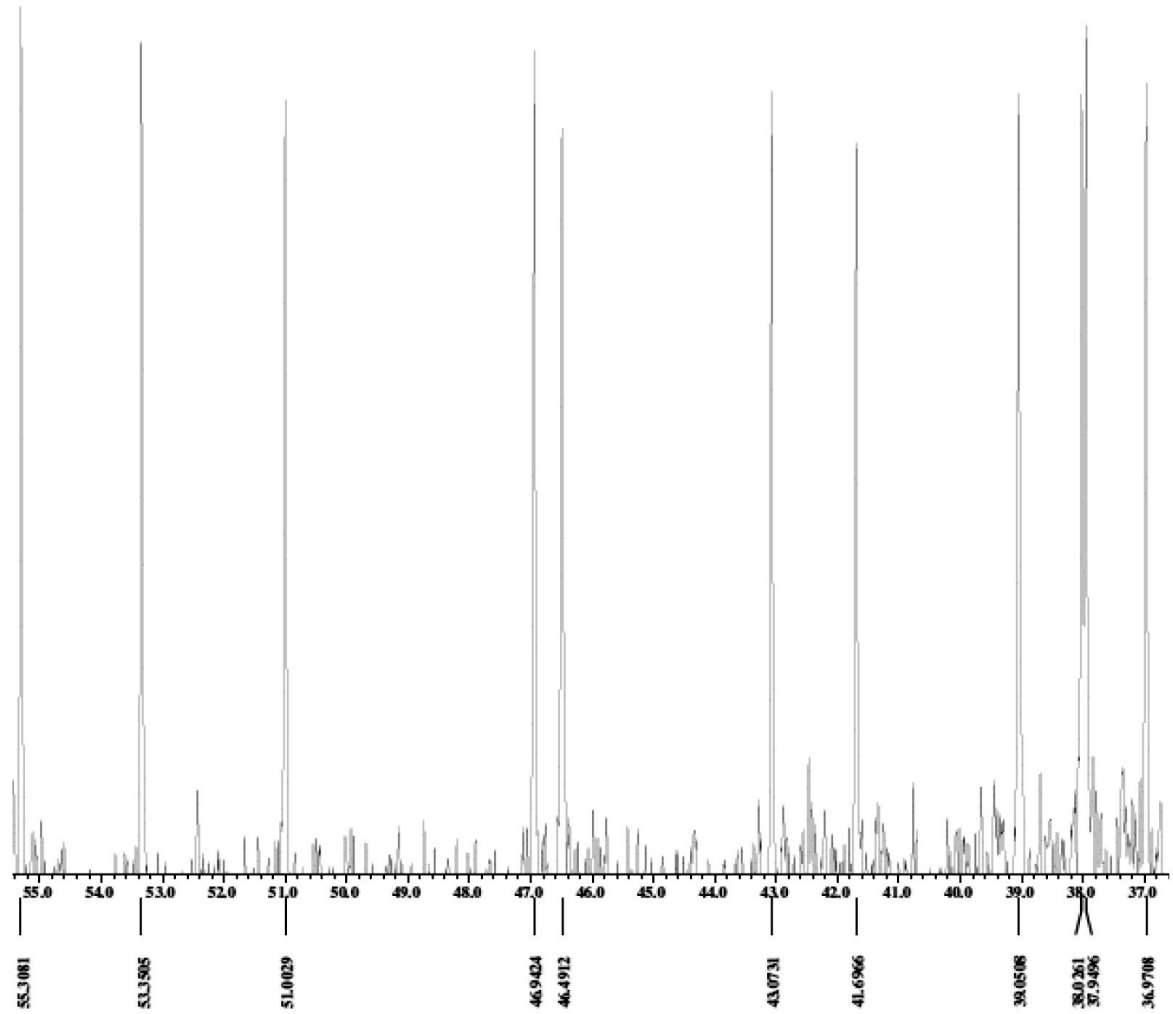

Figure S3. Expansion of ${ }^{13} \mathrm{C}$ NMR spectrum of triterpene $10\left(100 \mathrm{MHz}, \mathrm{CDCl}_{3}\right)$. 


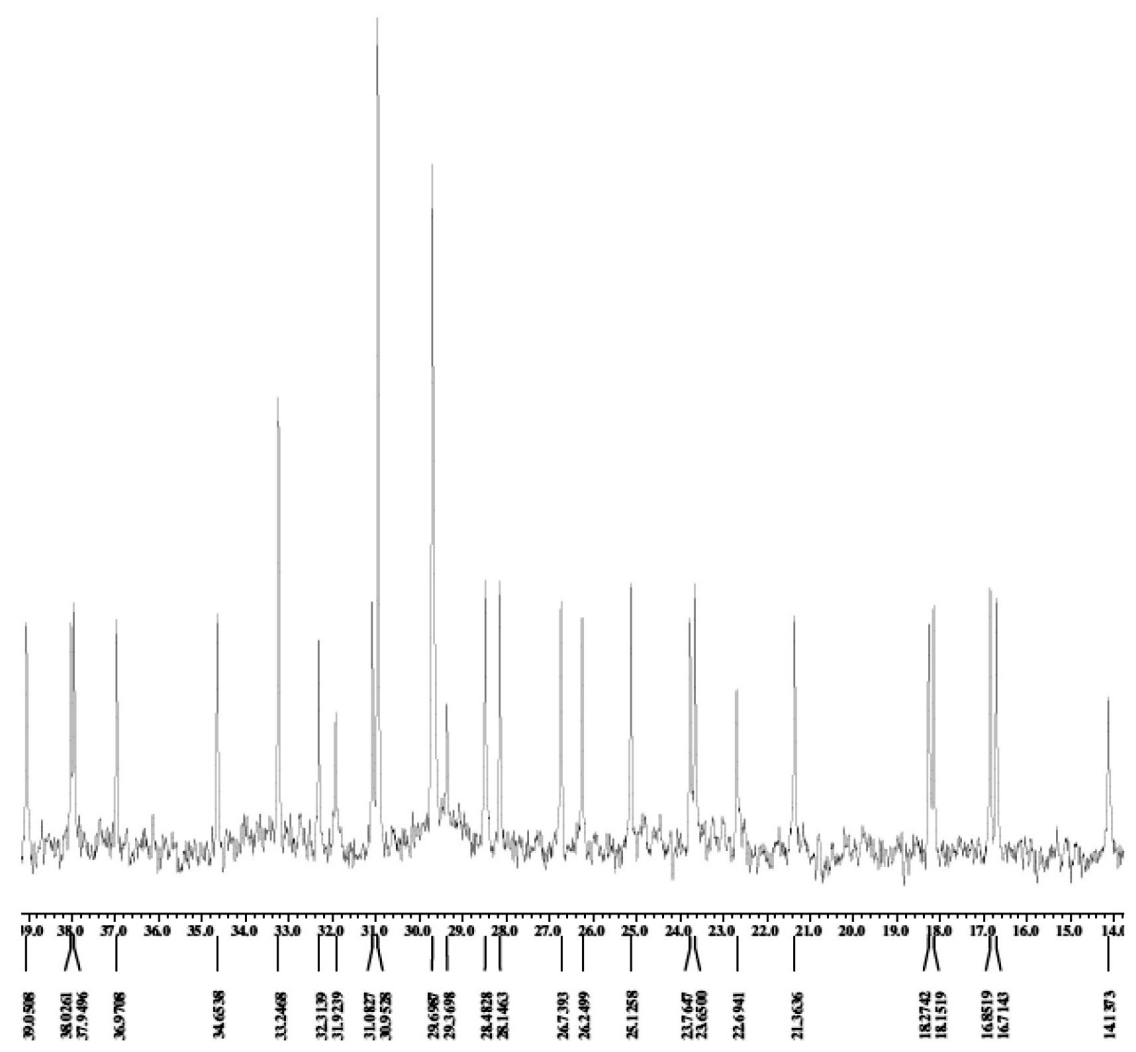

Figure S4. Expansion of ${ }^{13} \mathrm{C}$ NMR spectrum of triterpene $10\left(100 \mathrm{MHz}, \mathrm{CDCl}_{3}\right)$.

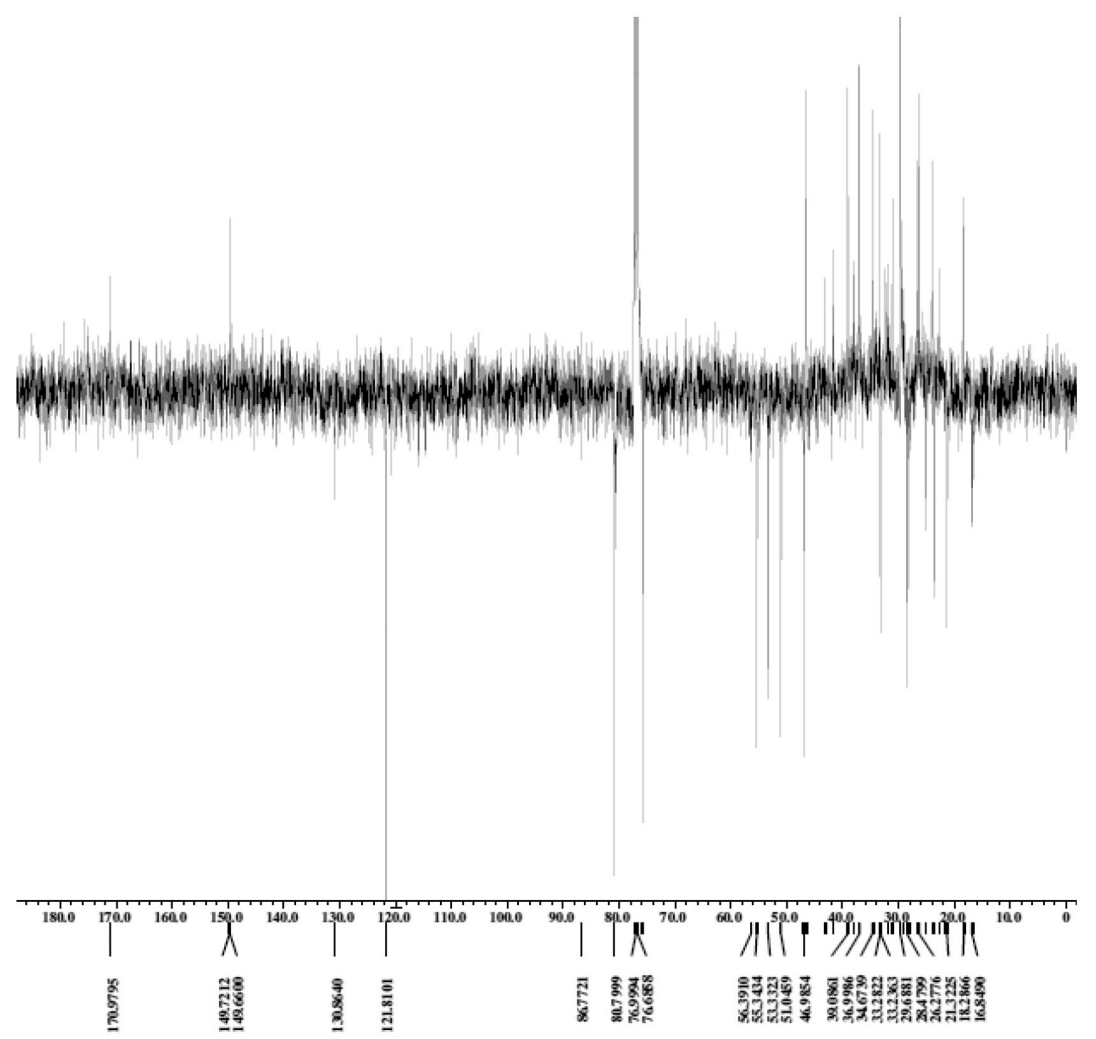

Figure S5. ${ }^{13} \mathrm{C}$ NMR-APT spectrum of triterpene $10\left(100 \mathrm{MHz}, \mathrm{CDCl}_{3}\right)$. 

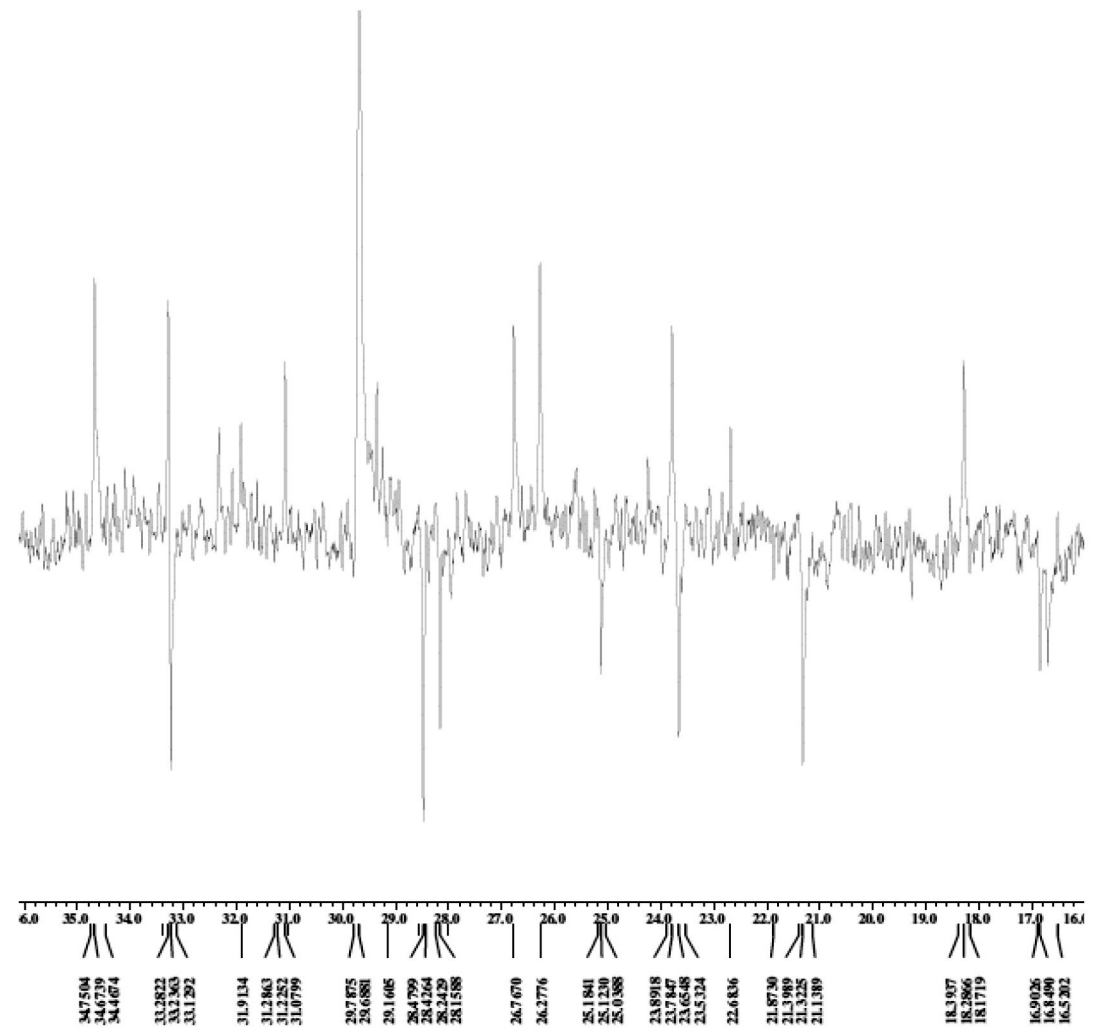

Figure S6. Expansion ${ }^{13} \mathrm{C}$ NMR-APT spectrum of triterpene $10\left(100 \mathrm{MHz}, \mathrm{CDCl}_{3}\right)$.

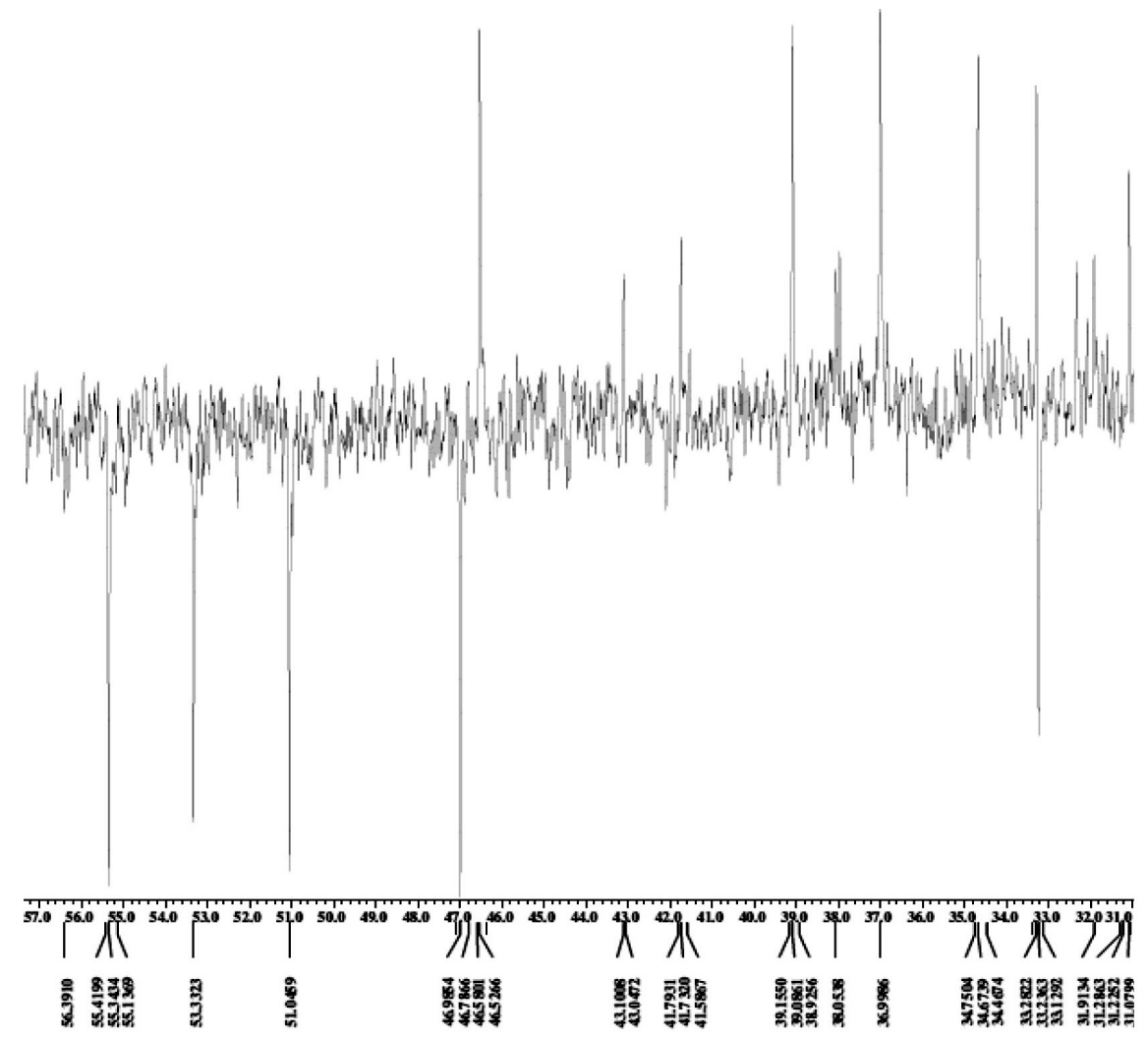

Figure S7. Expansion ${ }^{13} \mathrm{C}$ NMR-APT spectrum of triterpene $10\left(100 \mathrm{MHz}, \mathrm{CDCl}_{3}\right)$. 


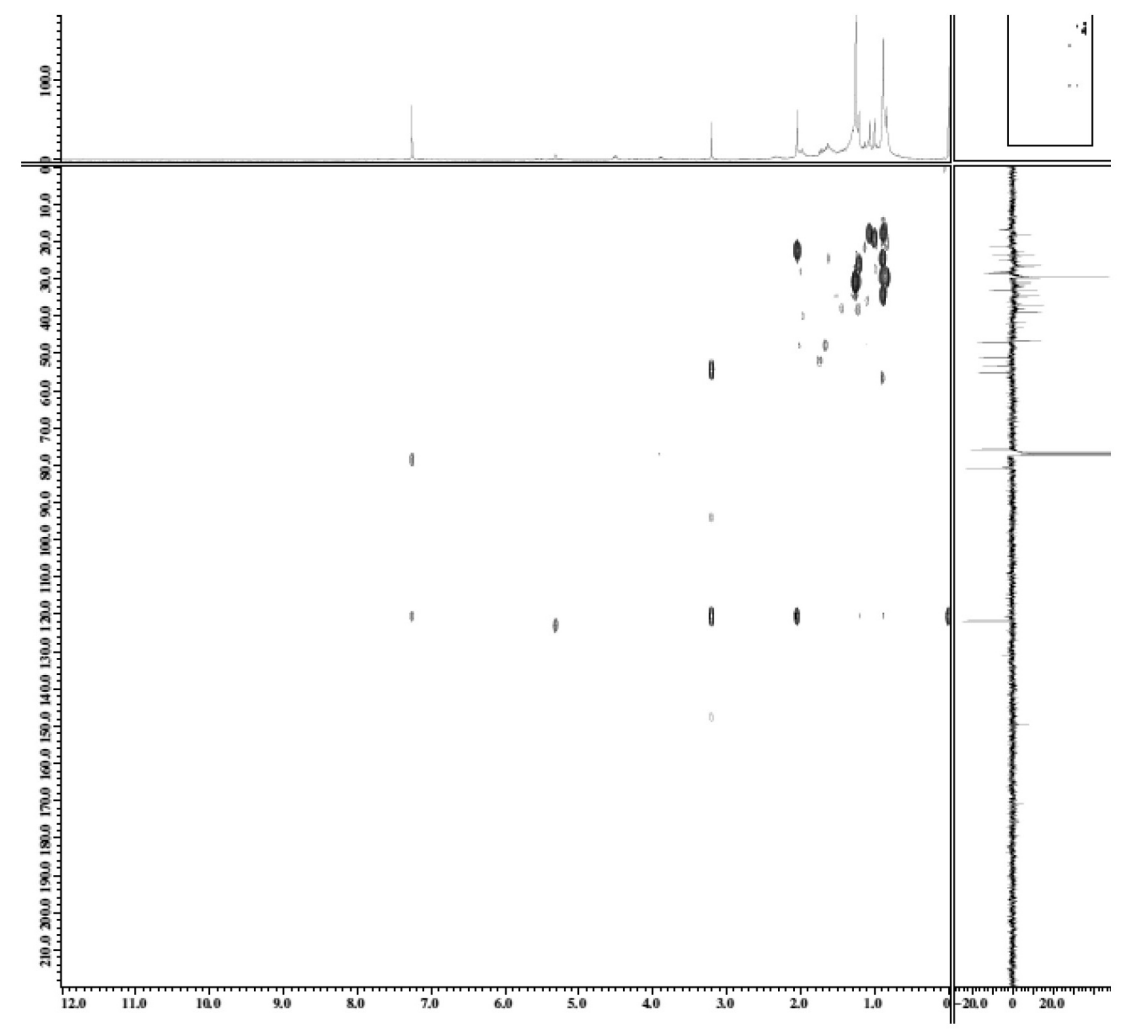

Figure S8. HMQC spectrum of triterpene $10\left(400 \mathrm{MHz}, \mathrm{CDCl}_{3}\right)$.

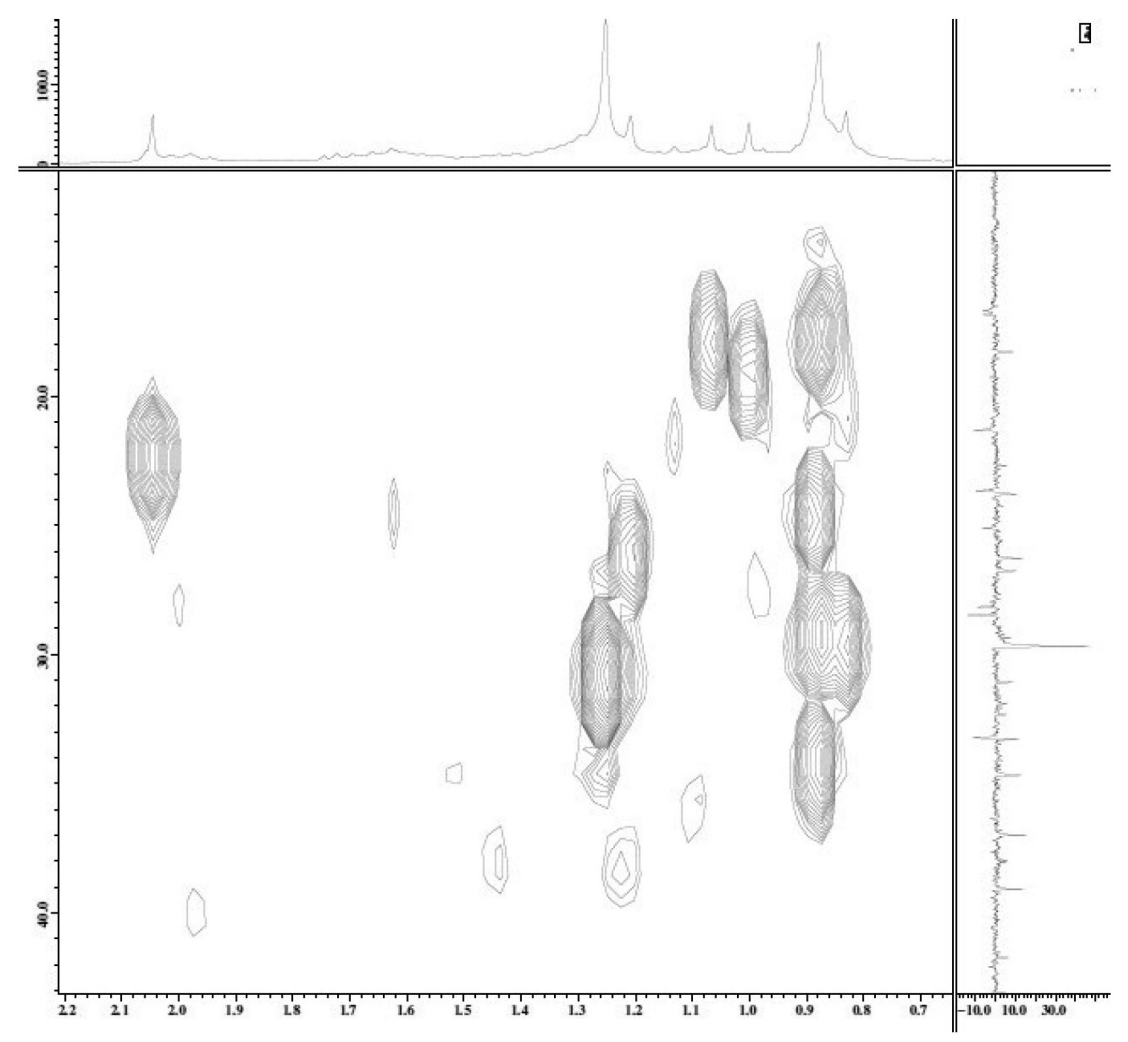

Figure S9. Expansion of $\mathrm{HMQC}$ spectrum of triterpene $\mathbf{1 0}\left(400 \mathrm{MHz}, \mathrm{CDCl}_{3}\right)$. 


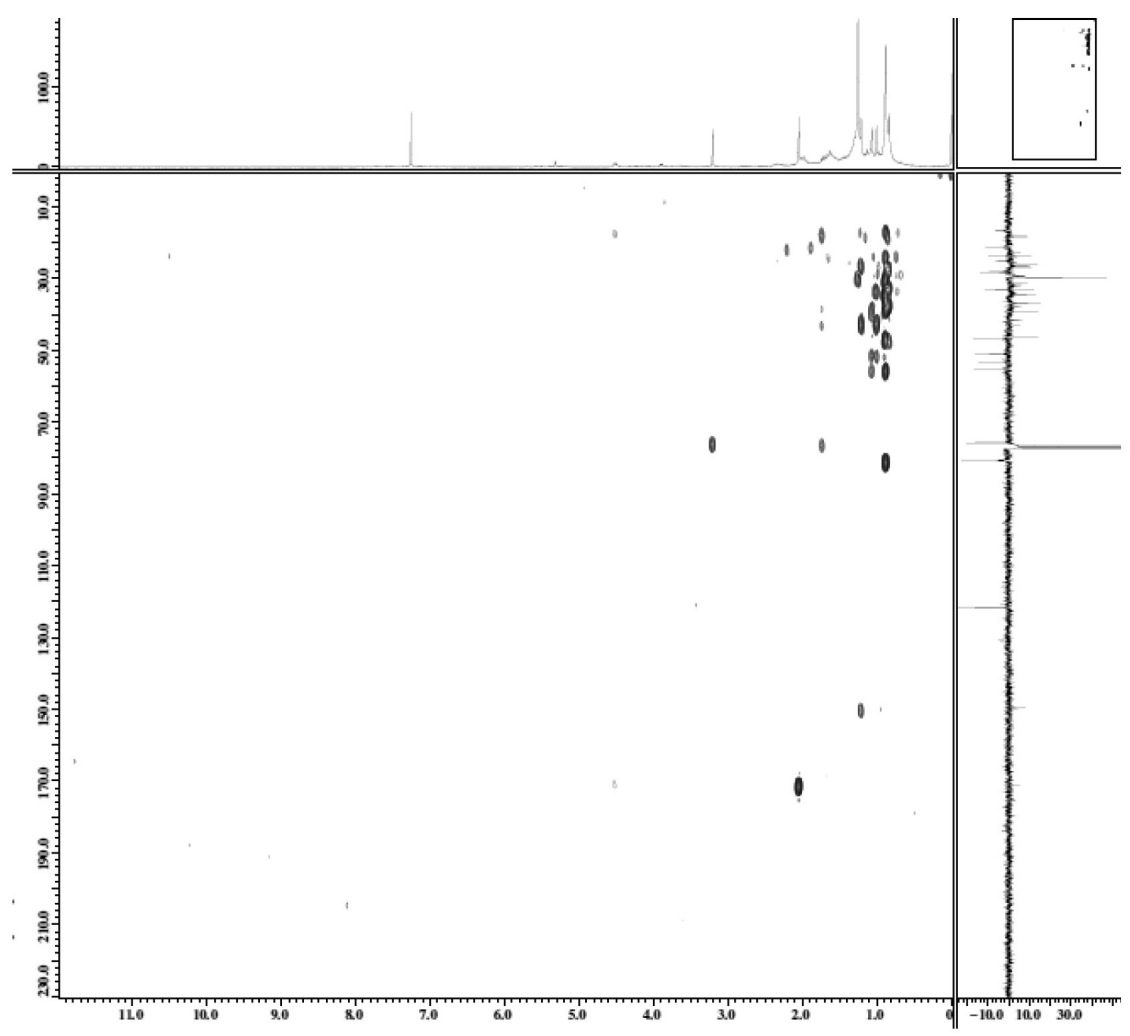

Figure S10. HMBC spectrum of triterpene $10\left(400 \mathrm{MHz}, \mathrm{CDCl}_{3}\right)$.

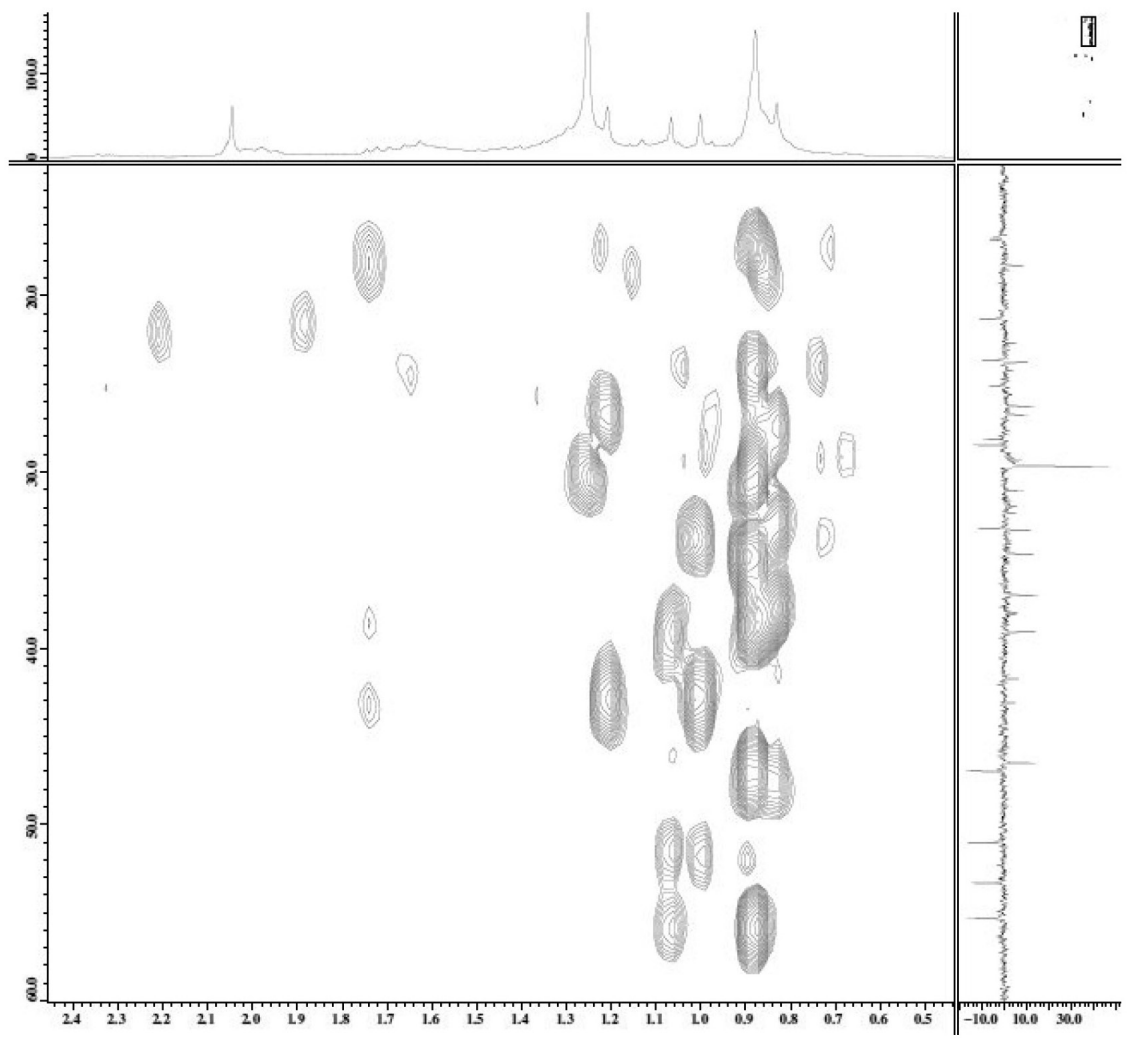

Figure S11. Expansion of $\mathrm{HMBC}$ spectrum of triterpene $10\left(400 \mathrm{MHz}, \mathrm{CDCl}_{3}\right.$ ). 


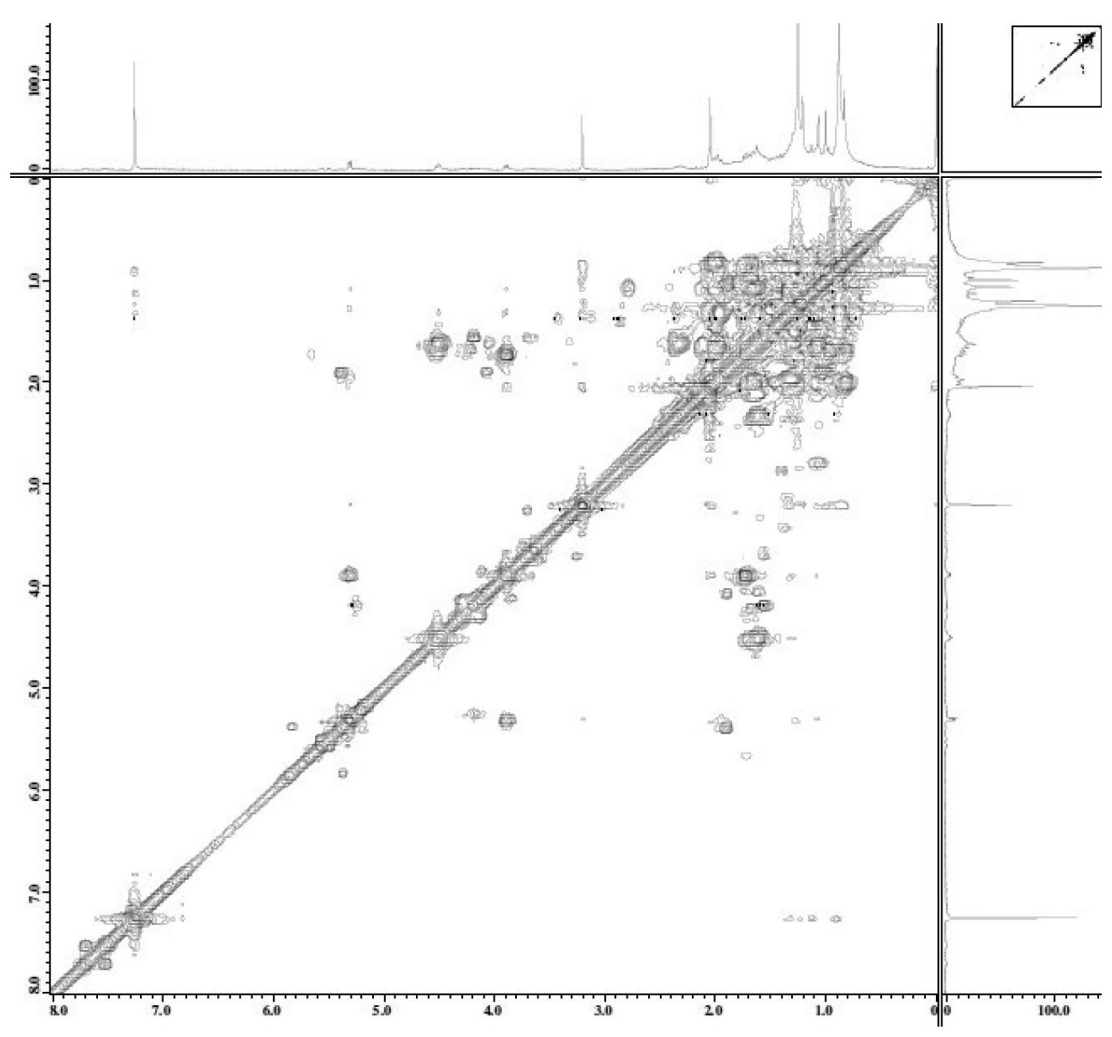

Figure S12. ${ }^{1} \mathrm{H}-{ }^{1} \mathrm{H}-\mathrm{COSY}$ spectrum of triterpene $10\left(400 \mathrm{MHz}, \mathrm{CDCl}_{3}\right)$.

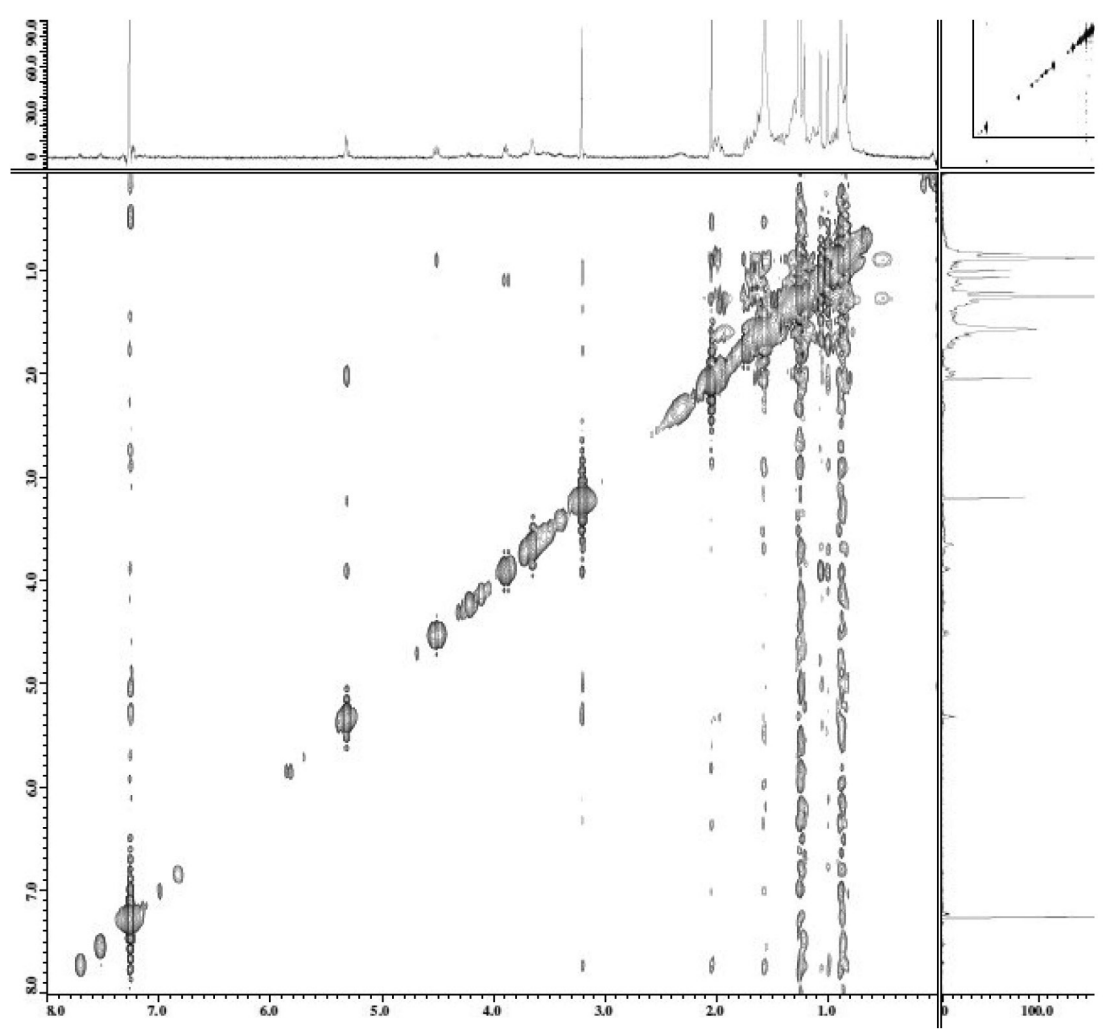

Figure S13. ${ }^{1} \mathrm{H}-{ }^{1} \mathrm{H}-\mathrm{NOESY}$ spectrum of triterpene $10\left(400 \mathrm{MHz}, \mathrm{CDCl}_{3}\right)$. 


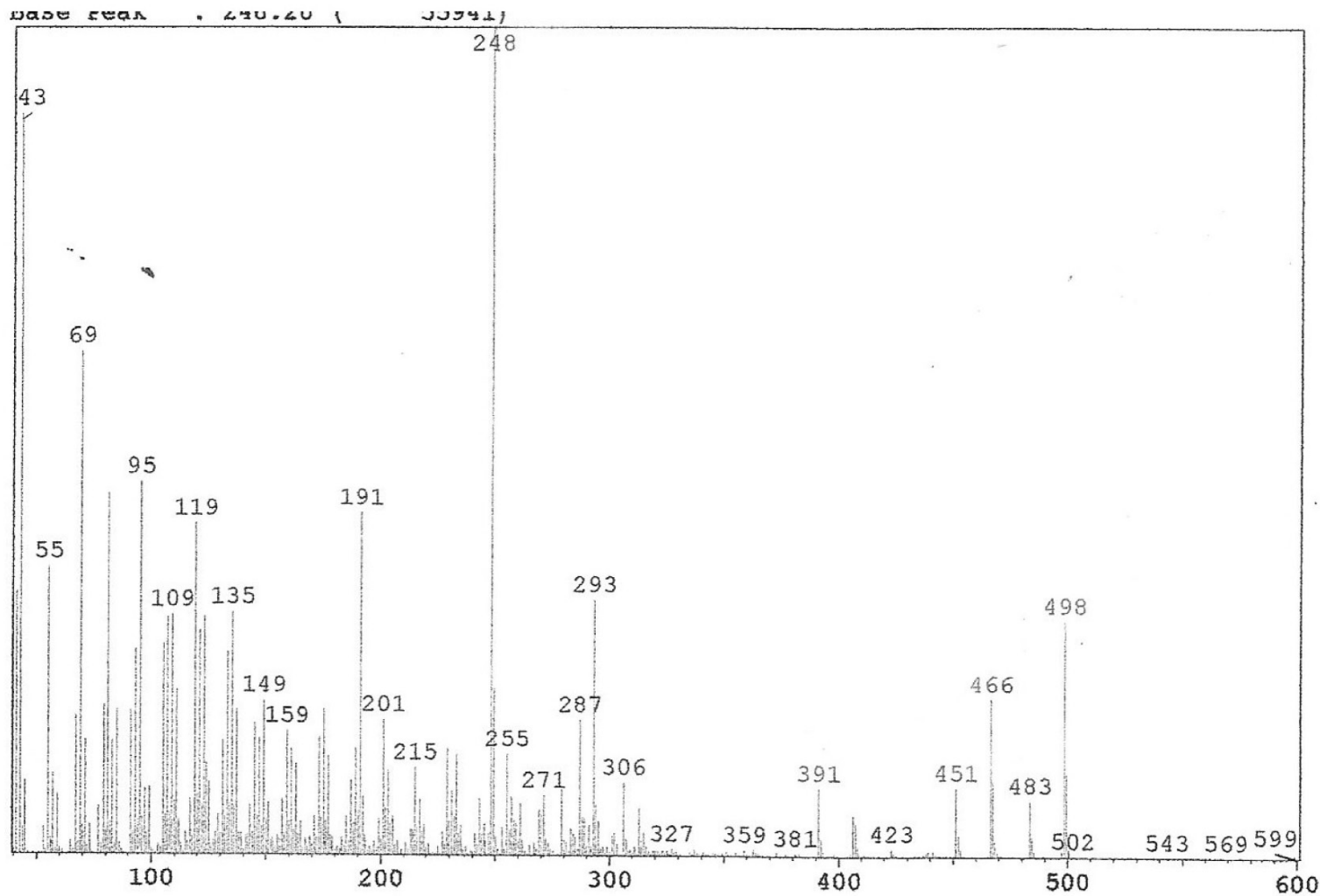

Figure S14. LREIMS spectrum of triterpene $10(70 \mathrm{eV})$.

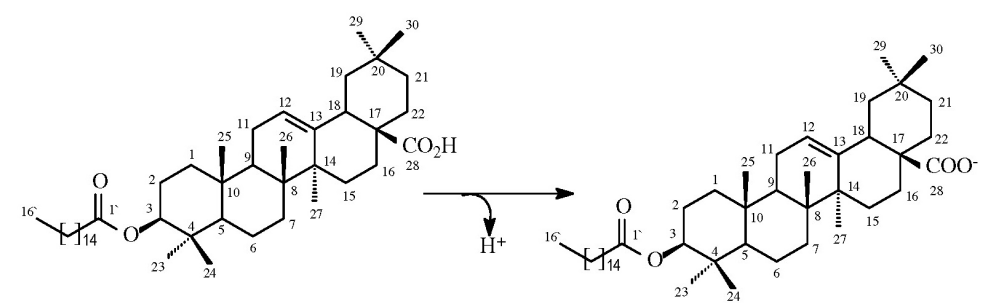<smiles>C=CC1=C(C)CCC2(C)CCC(C)(C)CC12</smiles>

$8 \mathrm{C}_{46} \mathrm{H}_{77} \mathrm{O}_{4}$

$\mathrm{m} / \mathrm{z} 693.582186$ $\mathrm{m} / \mathrm{z} 694.590011$ $\mathrm{m} / \mathrm{z} 693.5829(100 \%)$<smiles>CCCCCCCC(C)C</smiles>

$8 \mathrm{c} \mathrm{m} / \mathrm{z} 248(100 \%)$<smiles>CC1CC(C)C1[14CH3]</smiles>

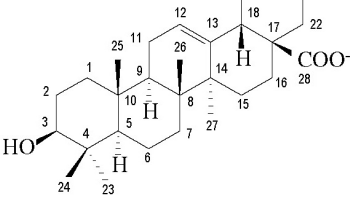<smiles>C=CC1=C(C)CCC2CCC(C)(C)CC12</smiles>

$8 b \mathrm{C}_{30} \mathrm{H}_{47} \mathrm{O}_{3}$ $\mathrm{m} / \mathrm{z} 455.352521$ $\mathrm{m} / \mathrm{z} 455.3578(30 \%)$

$8 \mathrm{~d} \mathrm{~m} / \mathrm{z} 203(60 \%$

Figure S15. Proposed fragmentation mechanisms of triterpene 8 by MS/MS (HRESIMS) of the peaks at $\mathrm{m} / z$ 693.5829 $\left(\left[\mathrm{M}-\mathrm{H}^{+}\right]^{-}\right)$with production of fragments $\mathbf{8 a}$ and $\mathbf{8 b}$ and EIMS (70 eV) to furnish $\mathbf{8 c}$ and $\mathbf{8 d}$, only peaks classified as principals. 


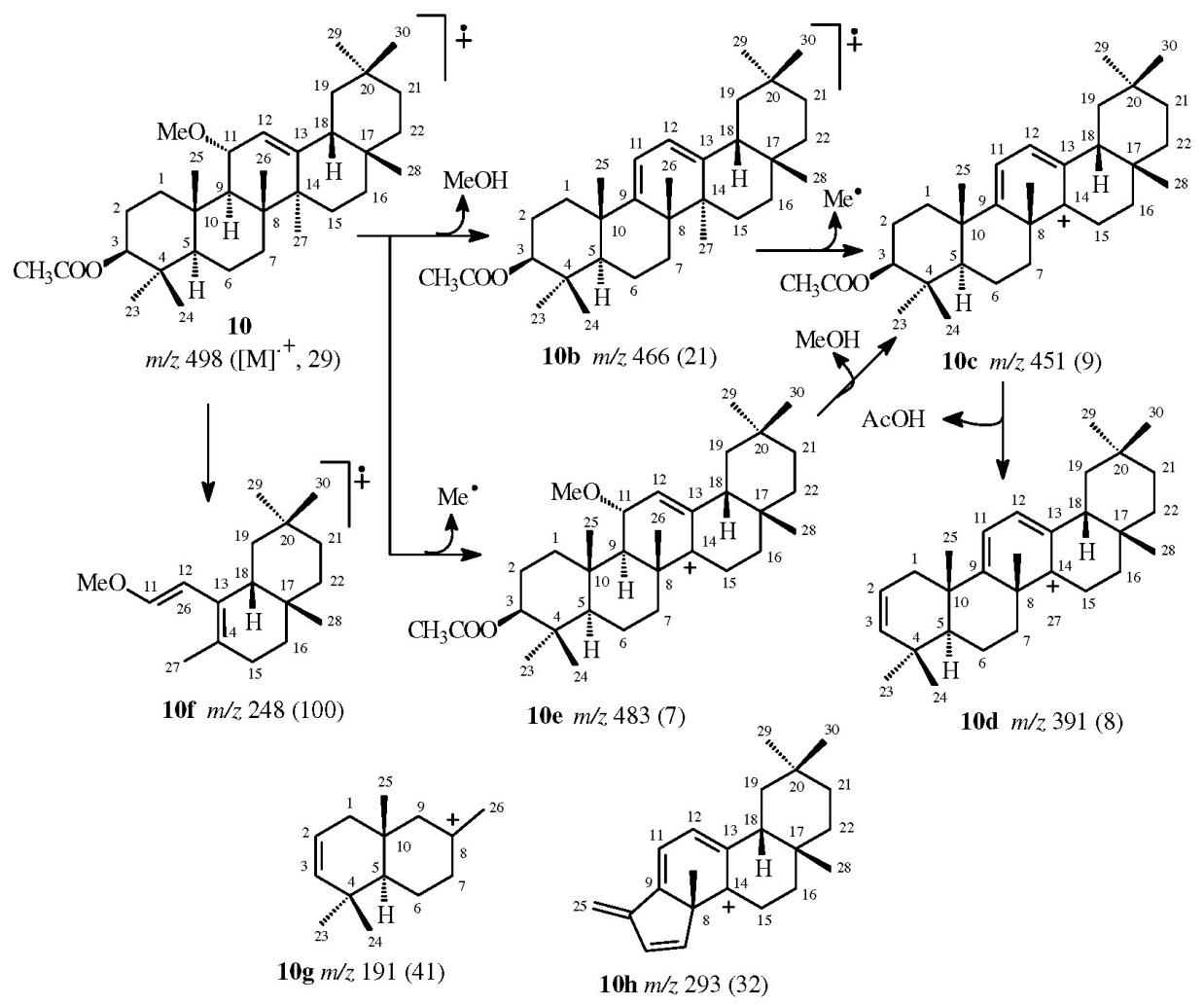

Figure S16. Proposed fragmentation mechanisms to justify principal peaks observed in the mass spectrum (LREIMS, $70 \mathrm{eV}$ ) of $\mathbf{1 0}$ (in parenthesis percentage of relative abundance). 